\title{
Competition between corn and a living mulch
}

\author{
R. C. Martin ${ }^{1}$, P. R. Greyson ${ }^{1}$, and R. Gordon² \\ ${ }^{1}$ Plant Science Department, Nova Scotia Agricultural College, Truro, Nova Scotia, Canada B2N 5E3, E-mail: \\ r.martin@nsac.ns.ca; ${ }^{2}$ Resource Stewardship Branch, Nova Scotia Department of Agriculture and Marketing, \\ Truro, Nova Scotia, Canada B2N 5E3, E-mail: rgordon@gov.ns.ca. Received 31 August 1998, \\ accepted 27 April 1999.
}

\begin{abstract}
Martin, R. C., Grayson, P. R. and Gordon, R. 1999. Competition between corn and a living mulch. Can. J. Plant Sci. 79: 579-586. Living mulches in row crops can reduce soil erosion, conserve soil moisture and control weeds; however, unless suppressed, they may also compete with the primary crop for light, nutrients and water. Therefore, the effects of mulch suppression were assessed on the development and yields of silage corn (Zea mays L.) in Truro, NS.

In 1995 and 1996, silage corn was grown in a living mulch composed of white clover (Trifolium repens L.) and mixed grasses in a $2 \times 5$ factorial design with eight replications. There were 2 levels of applied $\mathrm{N}$ : 0 and $115 \mathrm{~kg} \mathrm{~N}^{-1}$. The mulch was suppressed by: herbicide bands, roto-tilled strips, a combination of herbicide and roto-tillage, applied straw, and complete eradication with conventional tillage and herbicide applications (unmulched control treatment). Mulch between the corn rows was mowed several times, early in the season, to reduce competition.

In 1996, the control treatment yielded $11583 \mathrm{~kg} \mathrm{ha}^{-1}$, significantly more than $6844 \mathrm{~kg} \mathrm{ha}^{-1}$ in the combined herbicide and rototilled treatment, but in 1995 yields were not significantly different $(P>0.05)$ between these two treatments. Where only one method of mulch suppression was used (either roto-till or herbicide), corn yields in plots with living mulch were reduced by 39 to $72 \%$ relative to control plots. In both years, corn yields were higher at $115 \mathrm{~kg} \mathrm{~N}^{-1}$ than at $0 \mathrm{~kg} \mathrm{~N}^{-1}$. Yields in the mulched plots were 27\% lower in 1996 than in 1995, probably as a result of a late June 1996 frost. In addition to the increased risk of frost damage, the living mulch also delayed corn emergence and development. While there may be some reductions in herbicide use with living mulch, the risk in cool temperate climates of delayed development and reductions in yield may limit the use of living mulches to cool season crops.
\end{abstract}

Key words: Corn, frost, living mulch, reduced tillage, soil moisture

Martin, R. C., Greyson, P. R. et Gordon, R. 1999. Compétition entre le maïs et l'enherbement du sol. Can. J. Plant Sci. 79: 579-586. L'enherbement du sol dans les cultures sarclées peut contribuer à freiner l'érosion, à conserver l'eau du sol et à combattre les mauvaises herbes, mais à moins qu'on ne contienne sa croissance, il peut aussi disputer à la culture principale la lumière, les éléments nutritifs et l'eau nécessaires. Nous avons donc évalué les effets de diverses méthodes de maîtrise de la culture couvre-sol sur la croissance et sur le rendement du maïs ensilage (Zea mays L.) à Truro en Nouvelle-Écosse. En 1995 et en 1996, le maïs était cultivé dans un couvre-sol composé de trèffle blanc (Trifolium repens L.) et de diverses graminées, selon un dispositif factoriel $2 \times 5$ à 8 répétitions. Deux niveaux de fumure $\mathrm{N}$ étaient utilisés : 0 et $115 \mathrm{~kg} \mathrm{~N} \mathrm{ha}^{-1}$. La maîtrise du couvre-sol était obtenue 1) par l'épandage d'herbicide en bande, 2) par l'établissement et le maintien de laises de sol nu au moyen de traivail au motoculteur, 3) par la combinaison des herbicides et du travail au motoculteur, 4) par la pause d'un paillis de paille, 5) par l'éradication complète par labour classique et emploi d'herbicides (témoin, en sol nu). Le couvre-sol entre les lignes de maïs était fauché plusieurs fois au début de la saison de croissance pour atténuer la concurrence à l'égard de la culture. En 1996, le témoin produisait $11583 \mathrm{~kg} \mathrm{ha}^{-1}$ de fourrage, significativement plus que les $6844 \mathrm{~kg}$ obtenus dans la combinaison herbicide-travail au motoculteur, mais en 1995, il n'y avait pas de différences significatives $(P>0,05)$ entre les deux traitements. Lorsqu'une seule méthode de maîtrise du couvert était utilisée, c.-à-d. travail au motoculteur ou traitement herbicide, le rendement en maïs des parcelles avec couvre-sol était réduit de 39 à $72 \%$ par rapport au traitement témoin. Dans les deux années, le rendement du maïs était plus élevé dans les traitements recevant $115 \mathrm{~kg} \mathrm{~N} \mathrm{ha}^{-1}$ que dans le traitement des parcelles non fertilisées. Les rendements des parcelles avec couvre-sol étaient $27 \%$ plus bas en 1996 qu'en 1995, vraisemblablement la conséquence d'une gelée en fin de juin. En plus d'accroître les risques de dégâts par le gel, la culture couvre-sol retardait la levée et la croissance du maïs. Bien que cette technique autorise certaines réductions de l'emploi des herbicides, les risques de retard de croissance et de diminution de rendement associés aux climats tempérés frais incitent à réserver son application aux seules cultures de saison fraîche.

Mots clés: Maïs, gelée, culture couvre-sol, travail réduit du sol, état hydrique du sol

A relatively short, cool growing season in the maritime provinces often results in low corn yields and occasional crop failures. However, the development of early maturing hybrids has made corn production less risky. Conventional growing practices for corn include primary and secondary tillages. Weed control is achieved with both tillage and herbicides. No-till production is generally limited to coarser soils; under no-till regimes, soils tend to remain cool late into the spring and therefore delay planting (Mock and Erbach 1977).

No-till planting is used to reduce soil erosion, maintain soil organic matter and reduce nutrient leaching during winter months (Blevins et al. 1977; Hall et al. 1984). On the

Abbreviations: CHU, corn heat units; DM, dry matter; FDS, frost damage score; HI, harvest index 
other hand, weed control is more challenging with reduced tillage (Liebman and Dyck 1993) and crop yields are commonly maintained by herbicide use (Weersink et al. 1992). An alternative strategy is the use of living mulches.

Living mulches consist of an inter-row cover of low growing plant species to suppress weed growth, reduce runoff and limit soil erosion (Regnier and Janke 1990). With a permanent ground cover, runoff can be reduced by up to $98 \%$, and erosion can be reduced by 93 to $100 \%$ compared with tilled ground (Hall et al. 1984). While several nonlegumes have been evaluated as living mulches, legumes are preferred because of their reduced $\mathrm{N}$ requirements (Akobundu 1982; Regnier and Janke 1990).

It is possible that living mulches may compete for nutrients and reduce the yield of the primary crop. In Switzerland, Feil et al. (1997) measured leaf N-contents of corn grown in an Italian ryegrass (Lolium multiflorum Lam.) mulch, and reported lower concentrations from corn grown in a mulch compared with corn under conventional tillage. With sufficient suppression or where high proportions of legumes are grown, competition for $\mathrm{N}$ may be minimized (Blevins et al. 1977; Akobundu 1982; Grubinger and Minotti 1990). In New York, corn yields from a mulch of clover suppressed with rototilling once early in the growing season were as high as yields from bare ground plots, and corn leaf $\mathrm{N}$ levels were higher in the plots with suppressed clover (Grubinger and Minotti 1990).

The primary concern of living mulch systems is the extent of competition between the primary crop and the mulch (Wiles et al. 1989). Interference between the crop and living mulch can reduce both yield and quality. Therefore, the goal in living mulches is to minimize this interference through mulch suppression. To be an acceptable alternative for farmers, suppression must be practical and economical.

The purpose of this investigation was to assess the development and yield of corn and the composition and weight of living mulches when corn was grown in a grass/clover living mulch system, with reduced tillage. Comparisons were made between mulch suppression methods and two levels of $\mathrm{N}$.

\section{MATERIALS AND METHODS}

\section{Background and Experimental Design}

The study was conducted in 1995 and 1996 at the Brookside field of the Nova Scotia Agricultural College, Truro, Nova Scotia $\left(45^{\circ} 14^{\prime} \mathrm{N}, 63^{\circ} 19^{\prime} \mathrm{W}, 40 \mathrm{~m}\right)$. The site is located on a Woodville sandy loam (orthic humo-ferric podzol) soil (Nova Scotia Soil Survey 1991). The local area receives an average of $2200 \mathrm{CHU}$ annually (Bootsma et al. 1992). An established wild and somewhat patchy white clover population was present in the sward, which was dominated by pasture grasses, primarily bluegrass (Poa pratense), orchard grass (Dactylis glomerata), timothy (Phleum pratense), meadow fescue (Festuca arundinacea), Alopecurus pratensis) and various weed species such as quack grass (Elytrigia repens), common chickweed (Stellaria media) and dandelion (Taraxacum officinala). Within the tilled rows, there was also lamb's quarters (Chenopodium album) and pig weed (Amaranthus retroflexus).

\begin{tabular}{|c|c|c|}
\hline Treatment & $\begin{array}{l}\text { Nitrogen } \\
\left(\mathrm{kg} \mathrm{ha}^{-1}\right)\end{array}$ & Mulch suppression \\
\hline NOSUPP & $\begin{array}{c}0 \\
115\end{array}$ & $\begin{array}{l}\text { no mulch suppression, abandoned July } 1995 \\
\text { no mulch suppression, abandoned July } 1995\end{array}$ \\
\hline TILL & $\begin{array}{c}0 \\
115\end{array}$ & $\begin{array}{l}30 \mathrm{~cm} \text { tilled strip } \\
30 \mathrm{~cm} \text { tilled strip }\end{array}$ \\
\hline HERB & $\begin{array}{c}0 \\
115\end{array}$ & $\begin{array}{l}30 \mathrm{~cm} \text { herbicide band } \\
30 \mathrm{~cm} \text { herbicide band }\end{array}$ \\
\hline TILL/HERB & $\begin{array}{c}0 \\
115\end{array}$ & $\begin{array}{l}30 \mathrm{~cm} \text { herbicide band on top of } 30 \mathrm{~cm} \\
\text { tilled strip } \\
30 \mathrm{~cm} \text { herbicide band on top of } 30 \mathrm{~cm} \\
\text { tilled strip }\end{array}$ \\
\hline CONTROL & $\begin{array}{c}0 \\
115\end{array}$ & $\begin{array}{l}\text { conventional tillage and weed suppression } \\
\text { conventional tillage and weed suppression }\end{array}$ \\
\hline STRAW & $\begin{array}{c}0 \\
115\end{array}$ & $\begin{array}{l}\text { straw mulch placed over corn rows, } 1996 \\
\text { straw mulch placed over corn rows, } 1996\end{array}$ \\
\hline
\end{tabular}

Silage corn (Pioneer 3979) was grown in a living mulch which had been mechanically or chemically suppressed. The design was a $5 \times 2$ factorial arrangement in a randomized complete block design (RCBD). There were five levels of mulch suppression and two levels of $\mathrm{N}$ with eight replications, in the experimental design.

Emergence rates, in treatments with no prior mulch suppression, were low and corn growth and development was severely delayed compared with other treatments (Table 1). Therefore, these treatments were abandoned in 1995 and not repeated. The design was then analyzed as a $4 \times 2$ factorial with mulch suppression and $\mathrm{N}$ as the main factors. In 1996, an additional mulch suppression treatment of straw was added to replace the abandoned treatments and the design was analyzed as a $5 \times 2$ factorial. Individual plots were $8 \mathrm{~m}$ $\times 3.1 \mathrm{~m}$. Four corn rows, $0.76 \mathrm{~m}$ apart, running north-south, made up a single experimental unit. Grass buffer strips ( $3 \mathrm{~m}$ wide) were present between replications.

\section{Treatments}

Control Treatments

The control treatments (CONTROL- $0 \mathrm{~N}$ and CONTROL-115 N) were ploughed and disced. Weed suppression consisted of pre-emergence herbicide at rates of $1.5 \mathrm{~kg}$ a.i. ha ${ }^{-1}$ atrazine (2-chloro-4-ethylamino-6-isopropylaminos-triazine) and $1.1 \mathrm{~kg}$ a.i. ha ${ }^{-1}$ glyphosate ((isopropylamine salt of $\mathrm{N}$-(phosphono-methyl) glycine)) applied over the entire $8 \mathrm{~m} \times 3.1 \mathrm{~m}$ plot. Further weed suppression was accomplished with hand weeding, as required.

\section{Living Mulch Treatments}

In living mulch treatments (TILL, HERB and TILL/HERB), mulch suppression was achieved with either a $30 \mathrm{~cm}$ tilled strip or a $30 \mathrm{~cm}$ wide band of herbicide, or a combination of both. For mechanical suppression, a tractor mounted rototiller was used to till $30 \mathrm{~cm}$ wide strips in the sod before seeding. For chemical suppression a pre-emergence herbicide band at a rate of $1.5 \mathrm{~kg}$ a.i. ha ${ }^{-1}$ atrazine (2-chloro-4- 
ethylamino-6-isopropylamino-s-triazine) and $1.1 \mathrm{~kg}$ a.i. $\mathrm{ha}^{-1}$ glyphosate ((isopropylamine salt of $\mathrm{N}$-(phosphono-methyl) glycine)) was applied within a $30 \mathrm{~cm}$ band along the corn rows using a hand sprayer, thus reducing the application rate over the whole plot by $60 \%$. Corn was then planted into these suppressed strips.

\section{$N$ Treatments}

Nitrogen was applied in the form of ammonium nitrate, at a rate of $115 \mathrm{~kg} \mathrm{~N} \mathrm{ha}^{-1}$, according to recommendations of the Chemistry Laboratory of the Nova Scotia Department of Agriculture and Marketing after analyzing soil samples. Consistent with the design, other plots received no additional N. The fertilizer was applied on the soil surface within 10 $\mathrm{cm}$ of the corn rows and covered with a layer of straw to limit ammonia volatilization. The straw was approximately 1-2 cm deep, $10 \mathrm{~cm}$ wide, and added to all treatments.

\section{Straw Mulch Treatments}

In 1996, a combination treatment of tillage and a straw mulch was added to the plots which had no mulch suppression (NOSUPP) the previous season and had been abandoned. Straw was used to suppress the living mulch within the corn rows in a strip that had been roto-tilled in the sward just before seeding. On 8 July, a mulch of straw, 8-10 cm in depth, was placed approximately $15 \mathrm{~cm}$ on both sides of the rows as close to the corn as possible. The corn seedlings at this time were $10-15 \mathrm{~cm}$ high. On 18 July, the straw mulch was chopped and blown against the corn using a lawn mower, without damage to the corn.

\section{Field Preparation and Sampling}

A summary of all field activities for both years is shown in Table 2. All plots received $\mathrm{P}_{2} \mathrm{O}_{5}$ and $\mathrm{K}_{2} \mathrm{O}\left(30 \mathrm{~kg} \mathrm{ha}^{-1} \mathrm{P}_{2} \mathrm{O}_{5}\right.$ as triple-super-phosphate in both years and $95 \mathrm{~kg} \mathrm{ha}^{-1}$ and $40 \mathrm{~kg} \mathrm{ha}^{-1} \mathrm{~K}_{2} \mathrm{O}$ as $\mathrm{KCl}$ in 1995 and 1996, respectively) based on recommendations of the Chemistry Laboratory of the Nova Scotia Department of Agriculture and Marketing after analyzing soil samples. The fertilizer was applied by hand along the corn rows at a distance of approximately 4-6 $\mathrm{cm}$ from the corn.

The corn was planted with a no-till planter at a density of 68000 seeds ha ${ }^{-1}$. In 1996 only, the insecticide tefluthrin (Zeneca Agrochemicals) was applied in-furrow at a rate of 5 $\mathrm{kg} / \mathrm{ha}$. In 1996, six plots were too wet for the tractor on 6 June, and therefore were hand-planted the following day. The treatments were TILL-0 $\mathrm{N}$ in replicate 1, TILL/HERB-0 $\mathrm{N}$ in replicate 2, CONTROL- $0 \mathrm{~N}$ in replicate 5, TILL/HERB-0 N in replicate 7, and TILL/HERB-0 N and STRAW-115 $\mathrm{N}$ in replicate 8 .

The living mulch between the corn rows was mowed with a "string trimmer" when the average sward height reached $12 \mathrm{~cm}$. To determine when to mow, seven to ten measurements of the living mulch heights were performed in each plot at least twice weekly. The living mulch was then mowed to less than $3 \mathrm{~cm}$. Mowing between the corn rows ceased when the corn canopy closed in the CONTROL treatments. In both years, the canopy closed in the CON-

\begin{tabular}{lll}
\hline \multicolumn{2}{l}{ Table 2. Summary of field activities for $\mathbf{1 9 9 5}$ and $\mathbf{1 9 9 6}$} \\
\hline & 1995 & 1996 \\
\hline Ploughing, discing & 22 May & 17 May \\
Roto-tilling & 25 May & 3 June \\
Seeding & 26 May & 6 June \\
Mowing of mulch in & 5, 16, 28 June, & 17 June, \\
$\quad$ between corn rows & 11 and 20 July & 5 and 18July \\
Applied herbicide & 1 June & 11 June \\
Applied N, P and K & 6 June & 20 June \\
Autumn killing frost & 14 September & 24 September \\
Harvest & 30 September & 20 October \\
\hline
\end{tabular}

TROL treatments 2-6 days before the canopy closed in the mulch treatments.

Measurements of corn plant height and growth stage on 10 plants per plot (Hanway, 1989) were recorded 2-3 times weekly from emergence to silking, until more than $50 \%$ of the plants in a plot had reached the silking stage.

Two samples of mulch biomass were obtained before each mowing using a $0.2 \mathrm{~m} \times 0.5 \mathrm{~m}\left(0.1 \mathrm{~m}^{2}\right)$ quadrat and hand shears. For the within-row samples, the quadrat was placed perpendicular to and over a corn row. The between-row samples were taken with the quadrat placed parallel to and between two corn rows. Mulch samples were obtained from areas near the ends of each plot which were not part of the final harvestable area. All samples were dried and weighed. Two samples in 1995, and four in 1996, were separated by hand into clover, grass and weeds before drying and weighing.

For harvesting, all corn plants within an area of $4 \mathrm{~m}^{2}$ $(1.52 \mathrm{~m} \times 2.63 \mathrm{~m})$ in the center of each experimental unit were removed. The fresh weights of all plants from this sample were recorded, as well as the fresh weights of a subsample of four randomly selected plants from the harvested area. These four plants were oven dried and weighed. The kernels were separated from the cob, and the kernel weight measured. HI was calculated for the sample of four plants by dividing the DM weight of the kernels by the DM weight of the whole plant.

Volumetric soil water content was measured based on the time domain reflectometry method (Topp et al. 1980) using a Tektronix 1502C Metallic Cable Tester (Tektronix, Inc., Beaverton, Oregon). Measurements were performed 1-2 times weekly between 1100 and $1300 \mathrm{~h}$ throughout each field season for the $0-15,15-25$ and $50 \mathrm{~cm}$ soil depths. Each measurement was the average of six random measurements within each plot.

Meteorological data including rainfall (Model 6018-B Tipping Bucket Rain Gauges, Weathertronics, Sacramento, $\mathrm{CA})$ and air temperature $(\mathrm{Cu} / \mathrm{Co}$ thermocouples) were measured at the site. Data were recorded every $60 \mathrm{~s}$ and averaged hourly by a CR10 datalogger (Campbell Scientific Corp., Logan, UT). From temperature data collected at the site, daily CHU were calculated based on Brown (1969).

\section{Statistical Analysis}

Yield and Mulch Analysis

There were missing data points due to unsuccessful plots. In 1995 , three plots were abandoned in mid-July due to flood- 


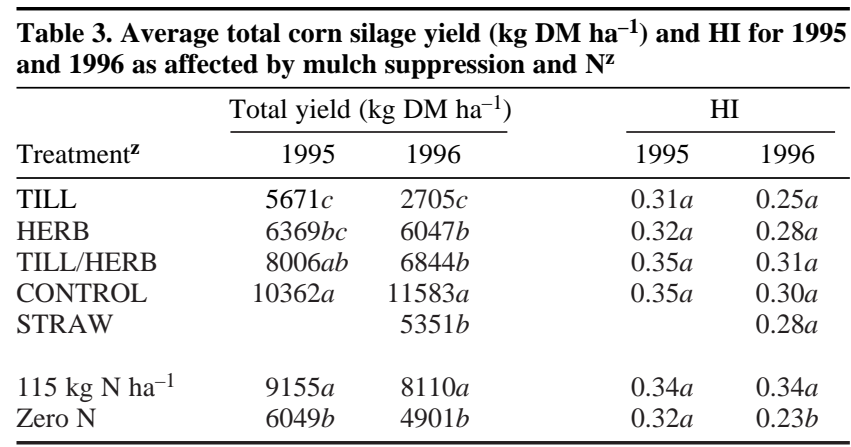

${ }^{\mathrm{z}}$ See Table 1 for treatment definitions.

$a-c$ Means in the same year in the same category with a different letter are significantly different $(P<0.05)$.

ing (TILL/HERB- $0 \mathrm{~N}$ in replicate 7, HERB-0 $\mathrm{N}$ and TILL/ HERB-0 N in replicate 8. In 1996, due to either poor germination or severe frost damage, the following plots were abandoned: CONTROL- $-0 \mathrm{~N}$ in replicate 2, STRAW-115 N in replicate 3, STRAW-0 N and $115 \mathrm{~N}$, TILL-0 N and 115 $\mathrm{N}$ in replicate 4, and STRAW- $0 \mathrm{~N}$ and $115 \mathrm{~N}$ and TILL/ HERB-0 $\mathrm{N}$ in replicate 8 . The LSMEANS statement was used to generate estimates of the means and the PDIFF function used to determine differences between treatments where main effects were found to be significant (SAS Institute, Inc. 1991). Interactions were assessed but reported only when significant. The significance level unless otherwise indicated was $P<0.05$.

\section{Frost Analysis}

On the night of 22 June 1996, the field site was hit by frost $\left(-1.8^{\circ} \mathrm{C}\right)$ and many seedlings were severely damaged. A frost damage rating was developed and recorded for each plant on 1 July and a visual frost damage score (FDS) based on the degree of foliar damage was calculated for each plot. Categories of damage were "severe", "moderate", and "minimal". This method and the following equation were developed during the research to assess relative damage:

$$
\mathrm{FDS}=3 \times \mathrm{pSEV}+2 \times \mathrm{pMOD}+1 \times \mathrm{pMIN}
$$

where pSEV is the proportion in each plot of severely damaged plants, pMOD is the proportion of moderately damaged plants, and pMIN is the proportion of minimally damaged plants. It was possible to derive an FDS for each plot ranging from 1 to 3 . If all plants in a plot were severely damaged, the score for that plot was 3.0. The resulting frost scores were used in the analysis comparing the amount of damage between different treatments.

\section{RESULTS AND DISCUSSION}

\section{Meteorological Conditions}

Rainfall during both growing seasons was higher than average (18\% in 1995 and 38\% in 1996) but showed somewhat different distribution during the two years. In both years, rainfall was higher than average in July (57\% in 1995 and
Table 4. Final corn heights and number of days from seeding to silking for 1995 and 1996 as affected by mulch suppression and $N^{z}$

\begin{tabular}{|c|c|c|c|c|}
\hline \multirow[b]{2}{*}{ Treatment ${ }^{\mathbf{z}}$} & \multicolumn{2}{|c|}{ Final heights $(\mathrm{cm})$} & \multicolumn{2}{|c|}{ Days to silking } \\
\hline & 1995 & 1996 & 1995 & 1996 \\
\hline TILL & $155 c$ & $133 c$ & $82 a$ & $88 a$ \\
\hline HERB & $171 b$ & $157 b$ & $80 a b$ & $81 b$ \\
\hline TILL/HERB & $184 a b$ & $172 b$ & $76 b$ & $81 b$ \\
\hline CONTROL & $192 a$ & $199 a$ & $76 b$ & $76 c$ \\
\hline STRAW & & $157 b$ & & $84 b$ \\
\hline $115 \mathrm{~kg} \mathrm{~N} \mathrm{ha}^{-1}$ & $187 a$ & $177 a$ & $77 a$ & $80 b$ \\
\hline Zero $\mathrm{N}$ & $164 b$ & $150 b$ & $79 a$ & $84 a$ \\
\hline
\end{tabular}

${ }^{\mathrm{z}}$ See Table 1 for treatment definitions.

$a-c$ Means in the same year in the same category with a different letter are significantly different $(P<0.05)$.

$101 \%$ in 1996), which is a critical period for corn development. However, rainfall was lower than average in August of both years (35\% in 1995 and $71 \%$ in 1996). Precipitation in June 1995 was $110 \%$ above average, but 33\% lower than normal in 1996. In September rainfall was $23 \%$ below normal in 1995 and 199\% above normal in 1996. The study site received $2237 \mathrm{CHU}$ between seeding and the first autumn frost in 1995, and 2186 CHU in 1996.

\section{Corn Silage Yields}

In 1995 and 1996, highest yields were in treatments without mulch (CONTROL) or where the living mulch had been suppressed the most (TILL/HERB) (Table 3). In 1995, there was no difference between the conventionally tilled treatments (10 $362 \mathrm{~kg} \mathrm{DM} \mathrm{ha}^{-1}$ ) and TILL/HERB (8006 kg DM $\mathrm{ha}^{-1}$ ). A similar local study, in 1994, had yields of 11573 and $11947 \mathrm{~kg} \mathrm{DM} \mathrm{ha}^{-1}$, for identical TILL/HERB and CONTROL treatments, respectively (Augustin 1994). The lowest yields in 1995 were for the living mulch treatments in which there was only one method of suppression (TILL and HERB). Yields for these treatments were $45 \%$ and $39 \%$ lower than the control treatment yields, respectively. There were no interactions between mulch suppression treatment and $\mathrm{N}$ application.

All mulch treatments in 1996 showed reductions $(P<0.05)$ in yield compared with CONTROL plots (Table 3). Yields for living mulch treatments TILL/HERB, HERB, and STRAW were $41 \%, 48 \%$ and $54 \%$ lower, respectively, than the conventional treatments. The mulch treatment with only strip tillage as mulch control (TILL) showed a $77 \%$ reduction in yield.

\section{Harvest Index}

Mulch suppression had no effect on HI in either year (Table 3). It is possible that this attribute is somewhat resistant to change. Duvick (1984) shows minimal or no change in HI over $50 \mathrm{yr}$ of corn breeding. Even under conditions where water, nutrients or light are limited, HI changes little (Duvick 1984; Tollenaar et al. 1997). Nevertheless, in our research, under excess competition from the mulch, low yielding corn in TILL $-0 \mathrm{~N}$ and HERB- $0 \mathrm{~N}$ had highly variable kernel weights and hence variable $\mathrm{HI}$. The $\mathrm{HI}$ for these 


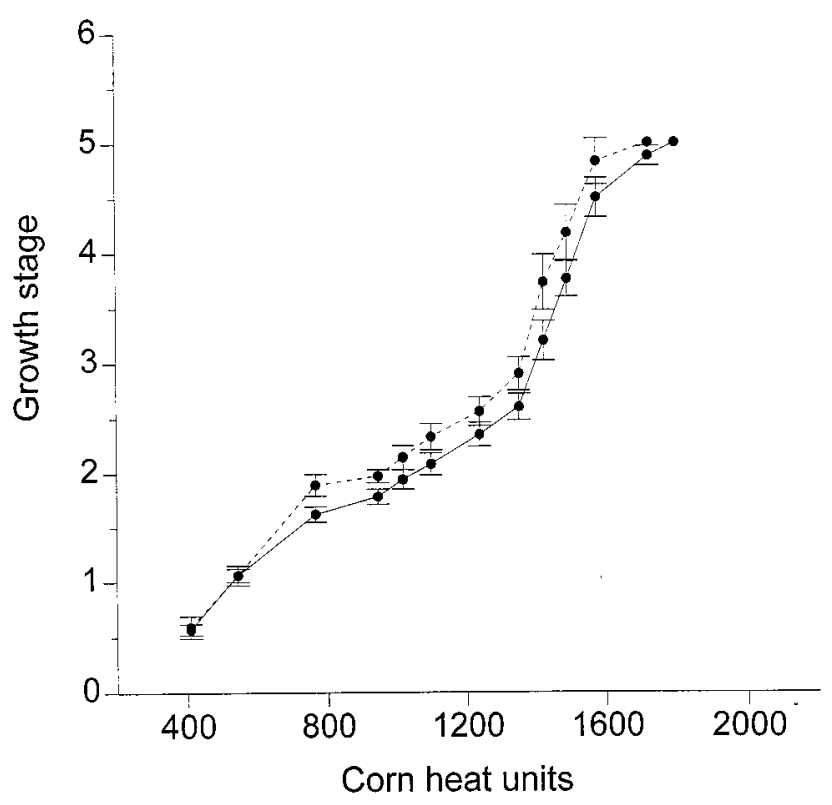

Fig. 1. Corn growth stage for mulch (_- ) and no-mulch (- - - -) treatments in 1995 as affected by heat unit accumulation. Error bars are equal to $\pm 2 \mathrm{SE}$.

treatments ranged between 0.04 and 0.37 . Nitrogen had a positive effect on $\mathrm{HI}$ in 1996. The average HI for treatments with $\mathrm{N}$ was 0.34 and without was 0.23 .

\section{Corn Growth Parameters}

Treatment effects on corn heights and days to silking were similar to those for yield (Table 4). The treatments producing the tallest and fastest-maturing plants were those without mulch. In 1995, both the mulch treatment with two methods of suppression (TILL/HERB ) and CONTROL produced plants that reached silking in $76 \mathrm{~d}$. Results of other treatments were 4 to $6 \mathrm{~d}$ later. In 1996, plants in CONTROL again reached silking in $76 \mathrm{~d}$, while those in the mulch treatments were delayed by 5 to $12 \mathrm{~d}$. In both years, the mulch in between the corn rows was mowed three times when its average plant height was $12 \mathrm{~cm}$, before the corn exceeded $13 \mathrm{~cm}$. Shading of the corn early in the season may have contributed to the delay in development.

Figures 1 and 2 show corn development as it is affected by CHU accumulation in both years. There was no difference in growth stage attained by the corn between the mulched treatments and CONTROL on any day during 1995. In 1996, however, development was delayed $(P<0.05)$ in the mulched plots, and the corn required approximately 400 more $\mathrm{CHU}$ to reach silking.

In 1996 , there was a $40 \%$ reduction in corn yield in the TILL/HERB compared with CONTROL. In addition, germination, emergence and phenological development were delayed, and final height was reduced. Corn grown with a living mulch was also severely damaged by the 22 June frost. Much of this developmental delay may be attributable to a reduction in soil temperature.

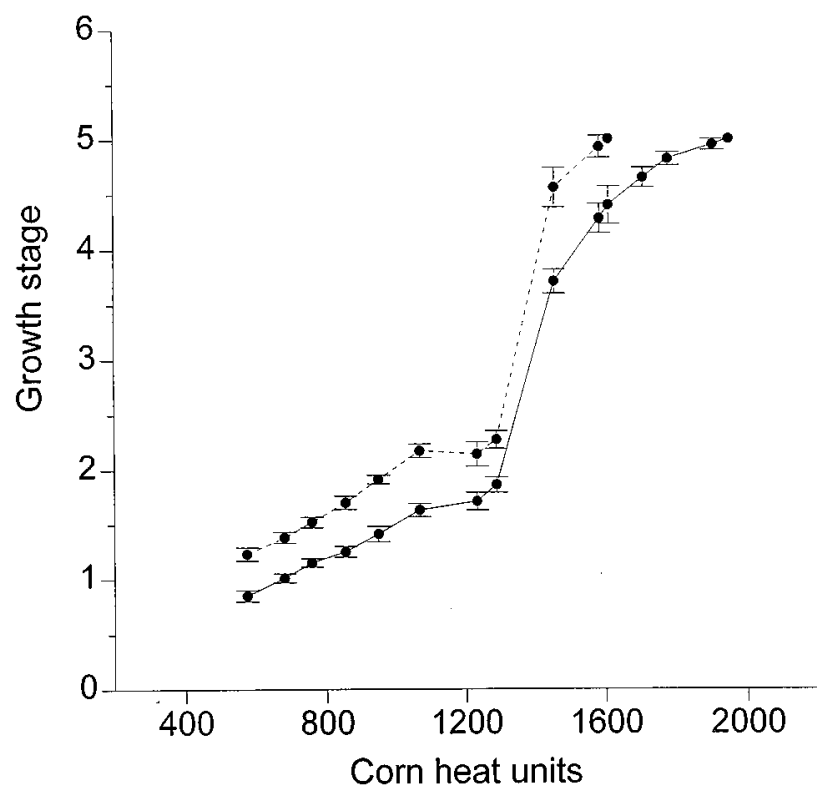

Fig. 2. Corn growth stage for mulch (- - ) and no-mulch (- - - ) treatments in 1996 as affected by heat unit accumulation. Error bars are equal to $\pm 2 \mathrm{SE}$.

Although soil temperature was not measured in this study, others have reported lower soil temperatures under mulches and in no-till conditions compared with bare soil and especially as it became drier (Adams et al. 1970; Mock and Erbach 1977). Soils in Atlantic Canada are often saturated early in the growing season (Gartley et al.1986).

\section{Living Mulches between Rows}

There were few differences in mulch DM on each sampling date (Table 5). On 18 July and 29 September 1995, HERB had mulch levels $50 \%$ and $67 \%$ higher, respectively, than the other treatments. HERB also had the highest mulch DM on 17 July 1996 and this treatment ranked first at all sampling dates but two, when it ranked second. However, despite the apparent extra competition, the corn yield of the HERB treatment was numerically greater than that under TILL in both years, with a significant difference in 1996 (Table 3). In 1996, STRAW had lower living mulch levels during the mid-season relative to HERB (Table 5), but corn silage yields were similar in these treatments (Table 3 ). Nitrogen had no effect on living mulch biomass between rows (data not shown in tables).

\section{Living Mulches within Rows}

In 1995, on the first sampling date (15 June) HERB had higher levels of living mulch DM within the corn rows than the other treatments (Table 6). Thereafter, TILL/HERB had lower mulch biomass within rows than TILL, and on 27 June and 8 July, mulch biomass was also lower in HERB/ TILL than in HERB. As could be expected with less competition, corn yield in the TILL/HERB ranked higher than that in the other treatments and was significantly greater 
Table 5. Between-row mulch dry matter $\left(\mathrm{kg} \mathrm{DM} \mathrm{ha}^{-1}\right)$ as affected by mulch suppression and $\mathrm{N}$ at five sampling dates in 1995 and four sampling dates in1996

\begin{tabular}{|c|c|c|c|c|c|c|c|c|c|}
\hline \multirow[b]{2}{*}{ Treatment $^{\mathbf{z}}$} & \multicolumn{5}{|c|}{1995 Sampling dates } & \multicolumn{4}{|c|}{1996 Sampling dates } \\
\hline & June 15 & June 27 & July 8 & July 18 & Sept. 29 & July 5 & July 17 & Aug. 14 & Oct 16 \\
\hline TILL & $1451 a$ & $870 a$ & $1117 a$ & $1141 b$ & $2150 b$ & $1028 a$ & $834 b$ & $1936 a$ & $2244 a$ \\
\hline HERB & $1522 a$ & $840 a$ & $1315 a$ & $1810 a$ & $3398 a$ & $1468 a$ & $1249 a$ & $2023 a$ & $1999 a$ \\
\hline TILL/HERB & $1441 a$ & $802 a$ & $1089 a$ & $1263 b$ & $1910 b$ & $1060 a$ & $878 b$ & $1663 b$ & $1728 a$ \\
\hline STRAW & & & & & & $1218 a$ & $942 b$ & $1467 b$ & $1850 a$ \\
\hline
\end{tabular}

${ }_{\mathrm{z}}^{\mathrm{z}}$ See Table 1 for treatment definitions.

$a, b$ Means followed by the same letter on the same sampling date and in the same category are not significantly different $(P>0.05)$.

Table 6. Within-row mulch dry matter $\left(\mathrm{kg} \mathrm{DM} \mathrm{ha}^{-1}\right)$ on five sampling dates as affected by mulch suppression and $\mathrm{N}$ in $1995^{\mathrm{Z}}$

\begin{tabular}{lccccc}
\hline & \multicolumn{5}{c}{ Sampling date } \\
\cline { 2 - 6 } Treatment $^{\mathbf{z}}$ & June 15 & June 27 & July 8 & July 18 & Sept. 29 \\
\hline TILL & $370 b$ & $659 a$ & $1234 a$ & $1796 a$ & $2345 a$ \\
HERB & $727 a$ & $783 a$ & $1105 a$ & $1337 b$ & $1813 b$ \\
TILL/HERB & $249 b$ & $358 b$ & $839 b$ & $1047 b$ & $1187 c$ \\
& & & & & \\
$115 \mathrm{~kg} \mathrm{~N} \mathrm{ha}^{-1}$ & $450 a$ & $675 a$ & $1096 a$ & $1466 a$ & $1560 b$ \\
Zero N & $446 a$ & $523 a$ & $1022 a$ & $1321 a$ & $2004 a$
\end{tabular}

${ }^{\mathrm{z}}$ See Table 1 for treatment definitions.

$a-c$ Means followed by the same letter on the same sampling date and in the same category are not significantly different $(P>0.05)$.

than that in TILL. Following a consistent trend of slightly more mulch biomass under applied $\mathrm{N}$, this treatment nevertheless resulted in less mulch biomass on 29 September and corn yields were higher with applied N (Table 3 ).

In 1996, TILL had more mulch biomass within rows than the other treatments on 17 July and 14 August (Table 7). Mulch biomass under TILL/HERB was only lower than HERB or STRAW at the first sampling and, according to expected competitive outcomes, corn yields were similar under TILL/HERB, HERB and STRAW treatments but lower under TILL (Table 3). Applied N resulted in more mulch biomass on 17 July, but differences were not evident at other dates, and the corn yield was higher under $115 \mathrm{~N}$.

\section{Percent Clover}

In 1995, the clover ranged from $6 \%$ to $18 \%$ and, in 1996, it ranged from $2.5 \%$ to $15 \%$ (Table 8 ). The remainder of the mulch was composed of grass and weed species. There were a number of areas within the study site with large concentrations of quack grass (Elytrigia repens [L.] Nevski). In 1995, HERB had higher clover proportions than TILL and TILL/HERB but, in 1996, there were no differences between treatments. The addition of $\mathrm{N}$ had no effect on the amount of clover in the sward in either year (data not shown in tables).

\section{Frost Effects}

On 22 June 1996, the FDS of CONTROL (1.56) was lower than those of TILL and STRAW (2.26), HERB (2.21) and TILL/HERB (2.14). The increased frost sensitivity can be attributed to higher soil moisture levels and lower temperatures under the mulch. Climate information for Truro from 1951 to 1980 (Environment Canada 1982) indicate that there

\begin{tabular}{|c|c|c|c|c|}
\hline \multirow[b]{2}{*}{ Treatment ${ }^{\mathbf{z}}$} & \multicolumn{4}{|c|}{ Sampling Date } \\
\hline & July 5 & July 17 & Aug. 14 & Oct 16 \\
\hline TILL & $463 a b$ & $735 a$ & $1815 a$ & $2421 a$ \\
\hline HERB & $559 a$ & $519 b$ & $1269 b$ & $1914 a$ \\
\hline TILL/HERB & $305 b$ & $376 b$ & $1140 b$ & $1754 a$ \\
\hline STRAW & $607 a$ & $413 b$ & $1036 b$ & $1533 a$ \\
\hline $115 \mathrm{~kg} \mathrm{~N} \mathrm{ha}^{-1}$ & $526 a$ & $568 a$ & $1246 a$ & $2077 a$ \\
\hline Zero N & $441 a$ & $453 b$ & $1384 a$ & $1734 a$ \\
\hline
\end{tabular}

${ }^{\mathbf{z}}$ See Table 1 for treatment definitions.

$a, b$ Means followed by the same letter on the same sampling date and in the same category are not significantly different $(P>0.05)$.

is a $10 \%$ chance of frost occurring later than 19 June, and there is a $25 \%$ chance of a spring frost later than 13 June.

\section{Soil Moisture}

Volumetric soil water (\%) measurements for both the CONTROL and mulch treatments throughout the 1996 growing season for $0-15,15-25$ and $50 \mathrm{~cm}$ depths are provided in Fig. 3. For each depth, the soil water content of the mulch treatment typically exceeded that of the conventional treatment. Frequent fluctuations in the soil water content occurred in the near surface layer $(0-15 \mathrm{~cm})$, which also had the greatest differences between the mulch plots and the CONTROL. A dry spell throughout the month of August contributed to a lowering of the CONTROL soil water content to approximately $5 \%$ in the $0-15 \mathrm{~cm}$ depth. The much treatment soil water content during this same period of time did not drop below $20 \%$.

Others have noted ( Kurtz et al. 1952; Jones et al. 1968) that soil moisture tends to be generally higher under living mulches and no-till. This effect appears to be primarily due to reduced evaporation and increased infiltration and percolation. While there may be higher soil moisture levels under mulch, its impact on corn yields is mitigated by reduced soil temperatures early in the season.

In conclusion, the combined herbicide and roto-tilled treatment had corn yields not different from yields in CONTROL in 1995 but, in 1996, CONTROL yields were higher. Where only one method of mulch suppression was used (either roto-till or herbicide) corn yields in plots with living mulch were reduced by $39-72 \%$ relative to CONTROL. In both years, corn yields were higher in plots with the $115 \mathrm{~kg}$ $\mathrm{N} \mathrm{ha}^{-1}$ treatment. Yields in the mulched plots were $27 \%$ 


\begin{tabular}{|c|c|c|c|c|c|c|}
\hline \multirow[b]{2}{*}{ Treatment $^{\mathbf{z}}$} & \multicolumn{2}{|c|}{1995 (\% clover) } & \multicolumn{4}{|c|}{1996 (\% clover $)$} \\
\hline & July 8 & Sept 29 & July 5 & July 17 & Aug 14 & Oct 16 \\
\hline TILL & $6.0 b$ & $5.8 b$ & $5.2 a$ & $2.5 a$ & $6.5 a$ & $4.2 a$ \\
\hline HERB & $18.3 a$ & $18.2 a$ & $11.9 a$ & $11.0 a$ & $15.0 a$ & $8.1 a$ \\
\hline TILL/HERB & $6.0 b$ & $6.8 b$ & $6.2 a$ & $5.9 a$ & $8.7 a$ & $3.9 a$ \\
\hline STRAW & & & $4.6 a$ & $3.5 a$ & $5.6 a$ & $3.7 a$ \\
\hline
\end{tabular}

${ }^{\mathrm{z}}$ See Table 1 for treatment definitions.

$a, b$ Means followed by the same letter on the same sampling date and in the same category are not significantly different $(P>0.05)$.

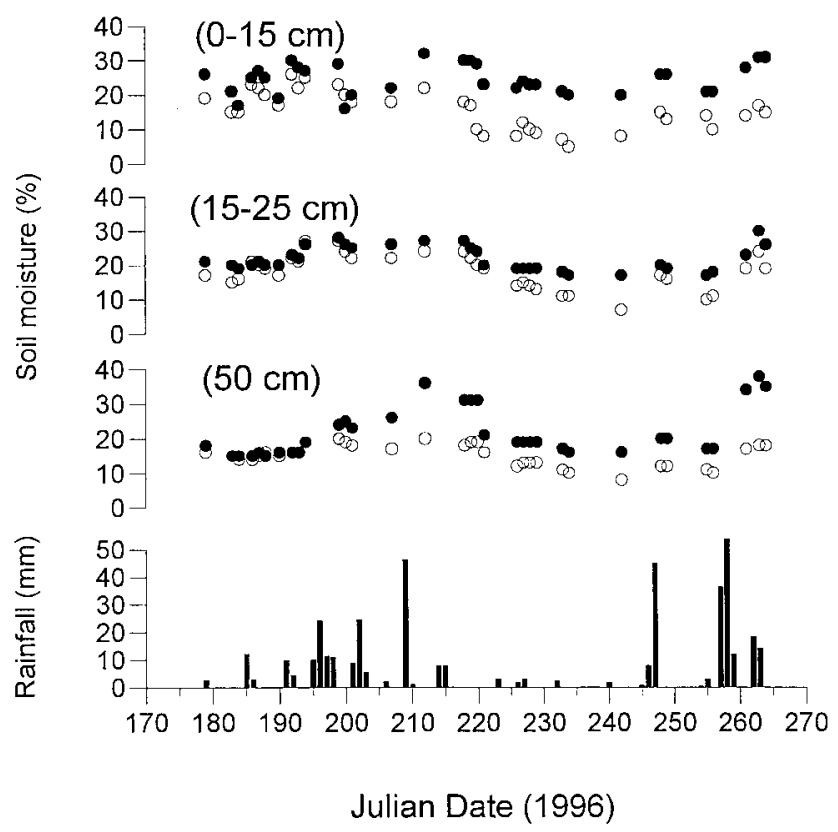

Fig. 3. Volumetric soil moisture content (\%) for 0-15 cm, 15-25 $\mathrm{cm}$ and $50 \mathrm{~cm}$ soil depths for both CONTROL (O) and TILL/HERB mulch $(-)$ treatments throughout the 1996 growing season. Precipitation is denoted by the vertical bars.

lower in 1996 than in 1995. This reduction may have been due to the effects of the late June frost. Corn in mulched plots was more frost sensitive than in CONTROL plots. The living mulch also delayed corn emergence and development. While there may be some reductions in herbicide use with living mulch, the risk of frost sensitivity, delayed development and yield reductions in cool temperate climates may limit the use of living mulches to cool season crops.

\section{ACKNOWLEDGMENT}

The authors thank Drs. T. Astatkie, G. N. Atlin and B. R.Christie for consultation during the experiment and for interpretation, thereafter. They acknowledge the helpful suggestions of anonymous reviewers. They also thank D. Langille and C. Donkin for technical assistance. They acknowledge the financial support of the National Science and Engineering Research Council.

Adams, W. E., Pallas, J. E. Jr. and Dawson, R. N. 1970. Tillage methods for corn-sod systems in Southern Piedmont. Agron. J. 62: 646-649.
Akobundu, I. O. 1982. Live mulch crop production in the tropics. World Crops (July/August): 125-126, 144-145.

Augustin, I. M. 1994. Evaluation of living mulches in corn. Fourth-year project. Nova Scotia Agricultural College, Truro, NS. Blevins, R. L., Thomas, G. W. and Cornelius, P. L. 1977. Influence of no-tillage and nitrogen fertilization on certain soil properties after 5 years of continuous corn. Agron. J. 69: 383-387. Bootsma, A., Gordon, R., Read, G. and Richards, W. G. 1992. Heat units for corn in the maritime provinces. Agdex No. 111.31. Atlantic Provinces Agricultural Services Co-ordinating Committee. Brown, D. M. 1969. Heat units for corn in southern Ontario. Information leaflet. Ontario Department of Agriculture and Food, Toronto, ON.

Duvick, D. N. 1984. Genetic contributions to yield gains of U.S. hybrid maize, 1930 to 1980. Pages 15-48 in W. R. Fehr, ed. Genetic contributions to yield gains of five major crop plants. CSSA Special Publication 7. ASA, Madison, WI.

Environment Canada. 1982. Canadian climate normals: 19511980. Canadian Climate Program. Environment Canada, Ottawa, ON.

Feil, B., Garibay, S. V., Ammon, H. U. and Stamp, P. 1997. Maize production in a grass mulch system: seasonal patterns of indicators of the nitrogen status of maize. Eur. J. Agron. 7: 171-179.

Gartley, C., Cochrane, L. and DeHaan, R. 1986. Farm drainage in the Atlantic provinces. AGDEX 752. ACAE Pub. \# 3. 19 pp.

Grubinger, V. P. and Minotti, P. L. 1990. Managing white clover living mulch for sweet corn production with partial rototilling. Am. J. Alt. Agri. 5: 4-12.

Hall, J. K., Hartwig, N. L. and Hoffman, L. D. 1984. Cyanazine losses in runoff from no-tillage corn in "living" and dead mulches vs. unmulched, conventional tillage. J. Environ. Qual. 13: 105-108. Jones, J. N., Moody, J. E., Shear, G. M., Moschler, W. W. and Lillard, J. H. 1968. The no-tillage system for corn (Zea mays L.). Agron. J. 60: 17-20.

Kurtz, T., Melsted, S. W., Bray, R. H. and Breland, H. L. 1952. Further trials with intercropping of corn in established sods. Soil Sci. Soc. Am. Proc. 16: 282-285.

Liebman, M. and Dyck, E. 1993. Crop rotation and intercropping strategies for weed management. Ecological Applications 3: 92122.

Mock, J. J. and Erbach, D. C. 1977. Influence of conservationtillage environments on growth and productivity of corn. Agron. J. 69: 337-340.

Nova Scotia Soil Survey. 1991. Soils of Colchester County, Nova Scotia. Report 19. Research Branch, Agriculture Canada, Ottawa, ON.

Regnier, E. E. and Janke, R. R. 1990. Evolving strategies for managing weeds. Pages 174-201 in C. A. Edwards, ed. Sustainable agricultural systems. Prentice Hall, Englewood Cliffs, NJ.

SAS Institute, Inc. 1991. SAS system for elementary statistical analysis. Cary, NC. 
Tollenaar, M., Aquilera, A. and Nissanka, S. P. 1997. Grain yield is reduced more by weed interference in an old than in a new maize hybrid. Agron. J. 89: 239-246.

Topp, G. C., Davis, J. L. and Annan, A. P. 1980. Electromagnetic determination of soil water content: Measurements in coaxial transmission lines. Water Resourc. Res. 16: 574-582

Weersink, A., Walker, M., Swanton, C. and Shaw, J. E. 1992. Costs of conventional and conservation tillage systems. J. Soil Water Conser. 47: 328-334.
Wiles, L. J., William, R. D., Crabtree, G. D. and Radosevich, S. R. 1989. Analyzing competition between a living mulch and a vegetable crop in an interplanting system. J. Am. Soc. Hortic. Sci. 114: $1029-1034$. 